\title{
The mechanism of antibacterial activity of corylifolinin against three clinical bacteria from Psoralen corylifolia L
}

https://doi.org/10.1515/chem-2018-0091

received December 25, 2017; accepted May 31, 2018.

Abstract: Effective antibacterial activity against Grampositive bacteria isolated in clinical strains was exhibited when corylifolinin was tested using the Disc diffusion method (K-B method). Minimum inhibitory concentration (MIC) of corylifolinin against Staphylococcus aureus (SA), Methcillin-resistant Staphylococcus aureus (MRSA) and extended spectrum $\beta$-lactamases Staphylococcus aureus (ESBLs-SA) were $0.078,0.156$ and $0.078 \mathrm{mg} / \mathrm{mL}$, respectively. The minimum bactericide concentrations (MBCs) were $0.156,0.156$ and $0.078 \mathrm{mg} / \mathrm{mL}$ respectively. Scanning electron microscopy (SEM), alkaline phosphatase (AKP) and bacterial extracellular protein leakage were used to investigate the antibacterial mechanism of corylifolinin. After adding corylifolinin at the MBC level, there were obvious changes to the Staphylococcus aureus of bacteria cells. Both MIC level and $\mathrm{MBC}$ levels of corylifolinin led to the leakage of AKP and bacterial extracellular protein.

Keywords: Corylifolinin; Antibacterial mechanism; Scanning electron microscopy; Bacterial membrane and wall permeability.

\section{Introduction}

The history of Traditional Chinese Medicines (TCMs) are thousands of years old. Many researchers in China are interested in studying TCMs because of their significant

*Corresponding author: Changyang Ma, Institute of Chinese Materia Medica, Henan University, Kaifeng, Henan, 475004, China; Kaifeng Key Laboratory of Functional Components in Health Food, Kaifeng, Henan, 475004, China, E-mail: macaya1024@sina.com Nan He, Juan Zhou, Miyun Hu, Wenyi Kang: Institute of Chinese Materia Medica, Henan University, Kaifeng,Henan, 475004, China Wenyi Kang: Kaifeng Key Laboratory of Functional Components in Health Food, Kaifeng, Henan, 475004, China

‡ These authors contributed equally to this work. Email: Nan HE: henanhenu@163.com; Juan ZHOU: 1145998028@qq.com health-promoting effects. Studies have shown that the compounds from TCMs have an effective antibacterial activity, such as the compounds isolated from the bark of Pterocarya stenoptera C. DC. [1], volatile oil of Pilea aquarum [2], extract of wild mushroom Fomes fomentarius (L.) Fr., Polyporaceae and flowers of Rhanterium adpressum [3,4] etc. The previous study of TCM components conducted by this research group, identified that corylifolinin was effective against the Gram-positive bacteria form Psoralen corylifolia L (P. corylifolia) [5].

$P$. corylifolia L., one member of the leguminous family, is widely distributed in Henan, Sichuan and Shanxi Provinces in China [6]. Coumarins, flavonoids, monoterpene phenols, coumarones, and steroids were found as the main compounds in $P$. corylifolia L [7]. Pharmacological investigations revealed that they exhibited anti-inflammatory, anti-hyperglycemic, anti-depressant, anti-microbial, anti-tumor, and antidermatophytic effects [8]. The research group isolated Corylifolinin, one of the 12 compounds from the $P$. corylifolia L. It showed a side chain of isopentenyl with anti-microbial activity [9]. It induced apoptosis in chronic leukemia noted in a previous report [10], and possessed strong anti-bacterial activity against Gram-positive bacteria [5]. Thus, it may be potentially used in common antibiotics. However, there is no report about an antibacterial mechanism of corylifolinin which may warrant further study corylifolinin and explore it as a commonly antibiotics. Therefore, in the present study, we investigated the antibacterial activities and mechanism underlying the effective antibacterial activities of corylifolinin.

\section{Materials and Methods}

\subsection{Clinically isolated strains and chemical reagents}

P. corylifolia Linn. was purchased from Le Ren Tang (Kaifeng, Henan, China) and identified by Professor 
Chang-qin Li of the Institute of Chinese Materia Medica, at Henan University, Kaifeng, Henan, China. The samples were as left at the Institute of Traditional Chinese Medicine, Henan University.

Gram-positive bacteria Staphylococcus aureus, methcillin-resistant Staphylococcus aureus, extended spectrum $\beta$-lactamases Staphylococcus aureus were isolated from Huaihe Hospital of Henan University (Zhengzhou, Henan, China). The AKP kit and protein assay kit were purchased from the Institute of Biotechnology (Nanjing Jiancheng, Jiangsu, China). The protein sample buffer 4x,N,N,N',N'-Tetramethylethylenediamine, Coomassie brilliant blue G-250 and glycine were purchased from SERVA. Other chemicals used in the study were of analytical grade.

\subsection{Isolation of corylifolinin}

The powdered $P$. corylifolia $(1.5 \mathrm{~kg})$ was extracted with petroleum ether three times for nine days at room temperature, then extracted with $70 \%$ aqueous ethanol at $50^{\circ} \mathrm{C}$ three times for nine hours. The extract was concentrated on a rotary evaporator to gain $150 \mathrm{~g}$, which was subjected to D101 column and eluted successively with $20 \%, 40 \%, 60 \%$ and $90 \%$ aqueous ethanol. Four (4) fractions were obtained. Sixteen grams of a $60 \%$ fraction were subjected to a silica gel column by gradient petroleum ether-ethyl acetate (30:1 2:1). Subfractions were subjected to Sephadex LH-20 and eluted with methanol to obtain corylifolinin.

$\mathrm{C}_{20} \mathrm{H}_{20} \mathrm{O}_{4}$, EI-MS: $\mathrm{m} / z$ 325(M+1)+, ${ }^{1} \mathrm{H}-\mathrm{NMR}\left(\mathrm{CDCl}_{3}\right): \delta 1.78$ $\left(3 \mathrm{H}, \mathrm{s}, \mathrm{CH}_{3}\right), \delta 1.82\left(3 \mathrm{H}, \mathrm{s}, \mathrm{CH}_{3}\right), \delta 3.5\left(2 \mathrm{H}, \mathrm{d}, \mathrm{CH}_{2}\right), \delta 5.3(1 \mathrm{H}$, t, CH), $\delta 6.4\left(1 \mathrm{H}, \mathrm{d}, J=9,5^{\prime}-\mathrm{H}\right), \delta 7.7\left(1 \mathrm{H}, \mathrm{d}, J=8.8,6^{\prime}-\mathrm{H}\right), \delta 7.4$ $(1 \mathrm{H}, \mathrm{d}, J=15.46, \alpha-\mathrm{H}), \delta 7.8(1 \mathrm{H}, \mathrm{d}, J=15.46, \beta-\mathrm{H}), \delta 6.9(2 \mathrm{H}, \mathrm{d}$, $J=9.11,3,5-\mathrm{H}), \delta 7.6$ (2H, d, $J=9.11,2,6-\mathrm{H})[5]$.

\subsection{Preparation of bacterial suspension and assays of antimicrobial activity}

\subsubsection{Preparation of bacterial suspension}

Three kinds of strains (SA, MRSA and ESBLs-SA) were expanded culture in petri dishes at $37^{\circ} \mathrm{C}$. To obtain strains on logarithmic growth phase, two colonies were picked up from each strain, inoculated into a $100 \mathrm{~mL}$ of sterile broth and cultured at $37^{\circ} \mathrm{C}$ with shaking at $120 \mathrm{r} / \mathrm{min}$. Finally, the concentration of bacteria was diluted with fresh broth to $1 \times 10^{7} \mathrm{CFU} / \mathrm{mL}[11]$.

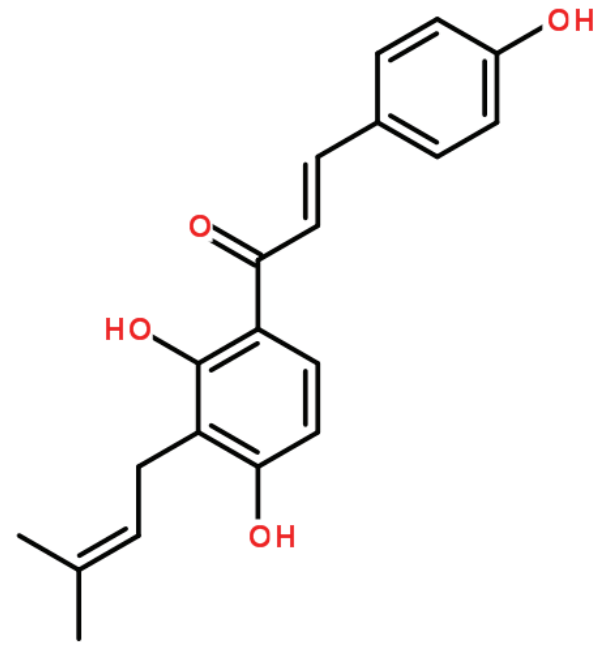

Figure 1: corylifolinin.

\subsubsection{Antibacterial Assay with Disk diffusion method (K-B method)}

The Disk diffusion method (K-B method) [12] was used to determine the antimicrobial activity of the corylifolinin. A sterile petri plate $(180 \mathrm{~mm})$ was prepared with $45 \mathrm{~mL}$ of nutrient broth medium, $200 \mu \mathrm{L}$ of bacterial suspension $\left(1 \times 10^{7} \mathrm{cfu} / \mathrm{ml}\right)$ spread onto the plates after solidifying and repeated twice. Sterile filter paper $(6 \mathrm{~mm})$ containing $20 \mu \mathrm{g}$ of corylifolinin was placed in the sterile agar plates after five minutes. DMSO was used as a control. Afterwards, the plates were incubated at $37^{\circ} \mathrm{C}$ for 24 hours. The antibacterial activity of corylifolinin was expressed by measuring the diameter of the inhibition zone (IZ). Values were described as the mean \pm SD of assays performed three times.

\subsubsection{Determination of minimum inhibitory concentration (MIC) and minimum bactericide concentration (MBC)}

MIC was defined as the lowest concentration of corylifolinin at which, there was no visible bacterial growth. MBC was defined as the lowest concentration of corylifolinin at which initial inoculum bacteria were killed.

MIC was determined by the Disk diffusion method (K-B method) according to the previously described method [13]. MBC was determined by the liquid culture method and plate count method [14]. First, the bacterial suspension $(90 \mu \mathrm{L}) /$ well was seeded into 96-well plates. Different concentrations of corylifolinin (MIC, $2 \times$ MIC, $3 \times$ MIC, $4 \times$ MIC, $5 \times$ MIC were added to a 96 wells, 
respectively, and mixed well. The plate was incubated at $37^{\circ} \mathrm{C}$ for 10 hours. Ten (10) $\mu \mathrm{L}$ of samples from each well were withdrawn and dropped into the agar and incubated at $37^{\circ} \mathrm{C}$ for 24 hours. The minimum concentration at which there were no more than five bacterial colonies was defined as MBC. Each test was performed three times.

\subsubsection{Determination of half $(50 \%)$ inhibitory concentration $\left(\mathrm{IC}_{50}\right)$}

Ninety (90) $\mu \mathrm{L}$ of bacterial suspension was mixed with $10 \mu \mathrm{L}$ of different concentrations of the residual liquid. Each mixture was added to each well with a solvent control, a blank control and a negative control. Each test was performed three times. The 96-well culture plate was incubated at $37^{\circ} \mathrm{C}$ for 24 hours. The absorbance at $595 \mathrm{~nm}$ $\left(\mathrm{OD}_{595}\right)$ was measured. All operations were performed under sterile conditions. The inhibition rate (\%) was calculated according to the formula [15] (1-1) as follows:

Inhibition rate $(\%)=\frac{(\text { solvent control wells OD-supernatantOD) - (liquidOD-supernatantOD) }}{\text { negative control OD-suprenatant OD }} \times 100 \%$

$1-1$

\subsection{Elucidation of antibacterial mechanism}

\subsubsection{Scanning electron microscopy (SEM) analysis}

The SA and MRSA ESBLs-SA (approximately $1 \times 10^{7} \mathrm{cfu} /$ $\mathrm{ml}$ ) were incubated with different concentrations of corylifolinin (control, MIC and MBC) at $37^{\circ} \mathrm{C}$ for 2,6 hours, respectively. The suspensions were centrifuged at 6500 rpm for ten minutes, and the pellet was washed twice with a $0.1 \mathrm{M}$ phosphate buffer solution (PBS). The bacterial cells were fixed with $2.5 \% \mathrm{v} / \mathrm{v}$ glutaraldehyde in $0.1 \mathrm{M}$ PBS for $24 \mathrm{~h}$ at $4^{\circ} \mathrm{C}$. The samples were dehydrated by sequential graded ethanol, which was replaced by $100 \%$ tertiary butyl alcohol. Finally, all the samples were sputter-coated with gold fixed on the freeze dryer for two minutes, followed by examining the ultra-structural changes of bacteria by the scanning electron microscope [16].

\subsubsection{AKP assay}

Different concentrations of corylifolinin (MIC, MBC, $2 \times \mathrm{MBC}$ and $3 \times$ MIC) were added to the bacterial suspension. Sterile distilled water was placed into the control group. The above culture media were placed in a shaker at $37^{\circ} \mathrm{C}, 120$ rpm according to instructions provided in the AKP kit. The supernatant was transferred to 96-well plates and mixed with a microplate reader. $\mathrm{OD}_{595}$ of each well was measured after being incubated for $0,0.5,1,2,3,4,5,6,7,8$ and 9 hours, respectively. Samples were measured three times. APK contents were calculated according to the formulas (1-2) [17].

$\mathrm{APK}=\frac{\text { sample } \mathrm{OD}-\text { control } \mathrm{OD}}{\text { standard } \mathrm{OD}-\text { control OD }} \times$ concentration of Phenol $\times 100 \mathrm{~mL} \times$ dilution ratio of sample $1-2$

\subsubsection{Extracellular soluble protein assay}

The integrity of cell membrane was evaluated by measuring the release of cell components, including nucleic acids and proteins, into cell suspension [18].

A sample was prepared the same way as the AKP assay. The untreated cell culture was fixed with $3.5 \% \mathrm{v} / \mathrm{v}$ propanediol and used as a control. All the samples were incubated at $37^{\circ} \mathrm{C}$ for $0,0.5,1,2,3,4,5,6,7,8$ and 9 hours, respectively. Absorbance value at $595 \mathrm{~nm}$ was measured after samples were mixed and kept in the dark for 10 minutes. Each test was performed three times. The concentration of bacterial extracellular proteins was calculated according to formulas (1-3) [18] as follows:

protein concentration $(\mathrm{g} / \mathrm{L})=\frac{\text { measuring tubeOD }- \text { blank tubeOD }}{\text { standard pipeOD } \text { blank tubeOD }}$ xconcentration of standard pipe $(0.563 \mathrm{~g} / \mathrm{L})$ $1-3$

\subsection{Statistical analysis}

All the experiments were performed three times. SPSS 20 and GraphPad Prism 5 were used for data analysis. Difference between groups with $P<0.05$ was regarded as statistically significant.

\section{Results and discussion}

\subsection{Antibacterial activity}

As shown in Table 1, corylifolinin exhibited relatively strong antibacterial activity against SA, MRSA and ESBLs-SA with the IZ values of 15.1, 13.1 and $12.0 \mathrm{~mm}$ at the concentration of $2.5 \mathrm{mg} / \mathrm{mL}$. The MIC for SA was $0.078 \mathrm{mg} / \mathrm{mL}$; the MBC was $0.156 \mathrm{mg} / \mathrm{mL}$. Both the MIC and MBC for MRSA were $0.156 \mathrm{mg} / \mathrm{mL}$. Both MIC and MBC of corylifolinin against ESBLs-SA were the lowest ones among the three kinds of Staphylococcus aureus. In 
Table 1: IZ, IC $C_{50}$, MIC and MBC of corylifolinin against the tested bacteria.

\begin{tabular}{|c|c|c|c|c|}
\hline Gram-positive bacteria & IZ (mm) ${ }^{a}$ & $\mathrm{IC}_{50}(\mathrm{mg} / \mathrm{mL})^{\mathrm{b}}$ & $\mathrm{MIC}(\mathrm{mg} / \mathrm{mL})^{\mathrm{c}}$ & $\mathrm{MBC}(\mathrm{mg} / \mathrm{mL})^{\mathrm{d}}$ \\
\hline SA & $15.1 \pm 0.2$ & $0.031 \pm 0.005$ & 0.078 & 0.156 \\
\hline MRSA & $13.1 \pm 0.2$ & $0.107 \pm 0.006$ & 0.156 & 0.156 \\
\hline ESBLs-SA & $12.0 \pm 0.3$ & $0.048 \pm 0.001$ & 0.078 & 0.078 \\
\hline
\end{tabular}

a IZ, diameter of inhibition zone, values represent mean of three replicates $\pm S D$, including diameteof disc 6 mm EO. Different letters within the same row express significantly differences between the means $(P<0.05) ; . \mathrm{b} I \mathrm{C}_{50}$, half inhibitory concentration; $\mathrm{c} \mathrm{MIC}$, minimal inhibitory concentration. And d MBC, minimal bactericide concentration.

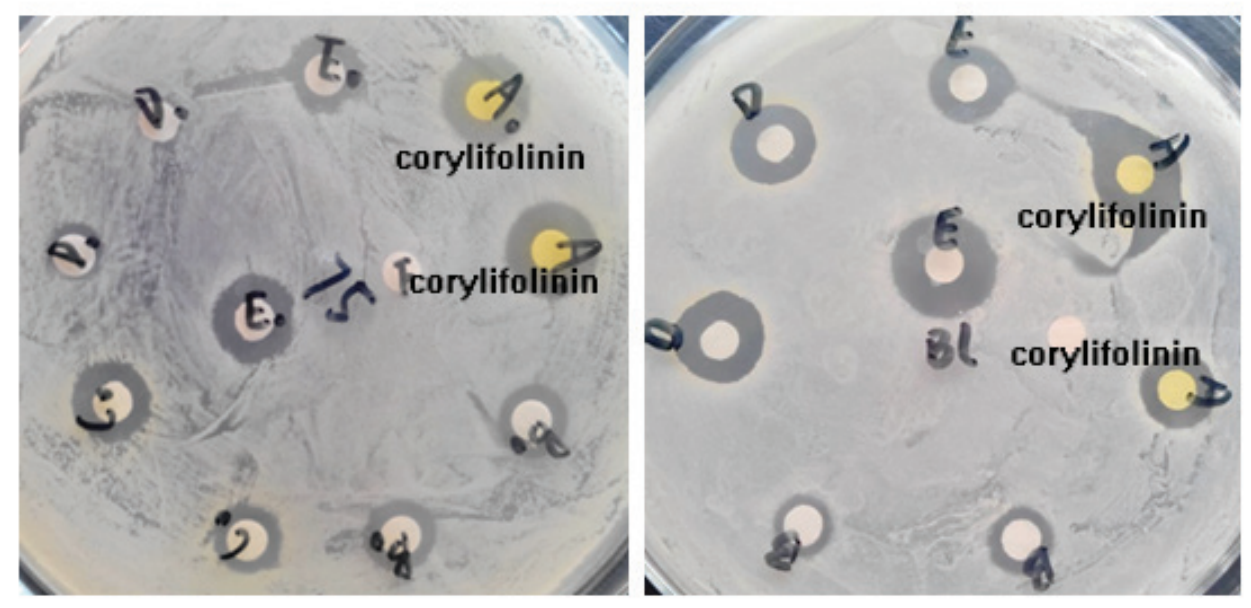

Figure 2: The inhibition zone of corylifolinin. ("75" represents Methcillin-resistant S. Aureus; BL represents Extended spectrum $\beta$-Lactamase producing S.aureus;)

general, bactericidal activity was defined with the rate of MBC/ MIC less than 4 [19]. And the results showed that the rate of MBC/ MIC of SA, MRSA, ESBLs-SA were 2, 1, 1, respectively.

All of above showed that corylifolinin had a relatively strong antibacterial activity against three clinically isolated bacterial strains.

\subsection{Changes in the ultrastructure of bacterial strains revealed by Scanning electron micro- scope (SEM) analysis}

The SEM has high magnification, more depth of field and strong stereoscopic perception. The changes in ultrastructure could be observed under SEM. Thus the changes in bacterial ultrastructure after being treated with corylifolinin could be observed clearly and directly by SEM. In Figure 2 (a, c and e), the surface of the bacteria untreated with corylifolinin was smooth and compact. Changes were observed in bacterial morphs and in the intracellular protein leakage to the extracellular when three strains (SA, MRSA and ESBLs-SA) treated with corylifolinin at MBC level for $6 \mathrm{~h}$ in Figure $2(\mathrm{~b}, \mathrm{~d}, \mathrm{f})$.

The above results showed that the levels of MBC were significantly different in the morphology and protein leakage of the bacteria, indicating that corylifolinin could affect the bacterial morphology as the cellular membrane of bacteria was destroyed and the substance in the cell were leaked.

\subsection{Leakage of AKP caused by corylifolinin treatment}

AKP mainly exists between the cell wall and cell membrane of the bacteria. AKP will be leaked into the extracellular due to the increasing permeability of the bacterial cell wall. The results of AKP leakage assay can indirectly reflect the integrity of the bacterial cell wall [20,21].

In Figure 3 (A1, B1, and $\mathrm{C} 1$ ), the leakage of AKP in corylifolinin-treated groups at the MIC level was significantly higher than that of the control group. The leakage of AKP was correlated with the corylifolinin 

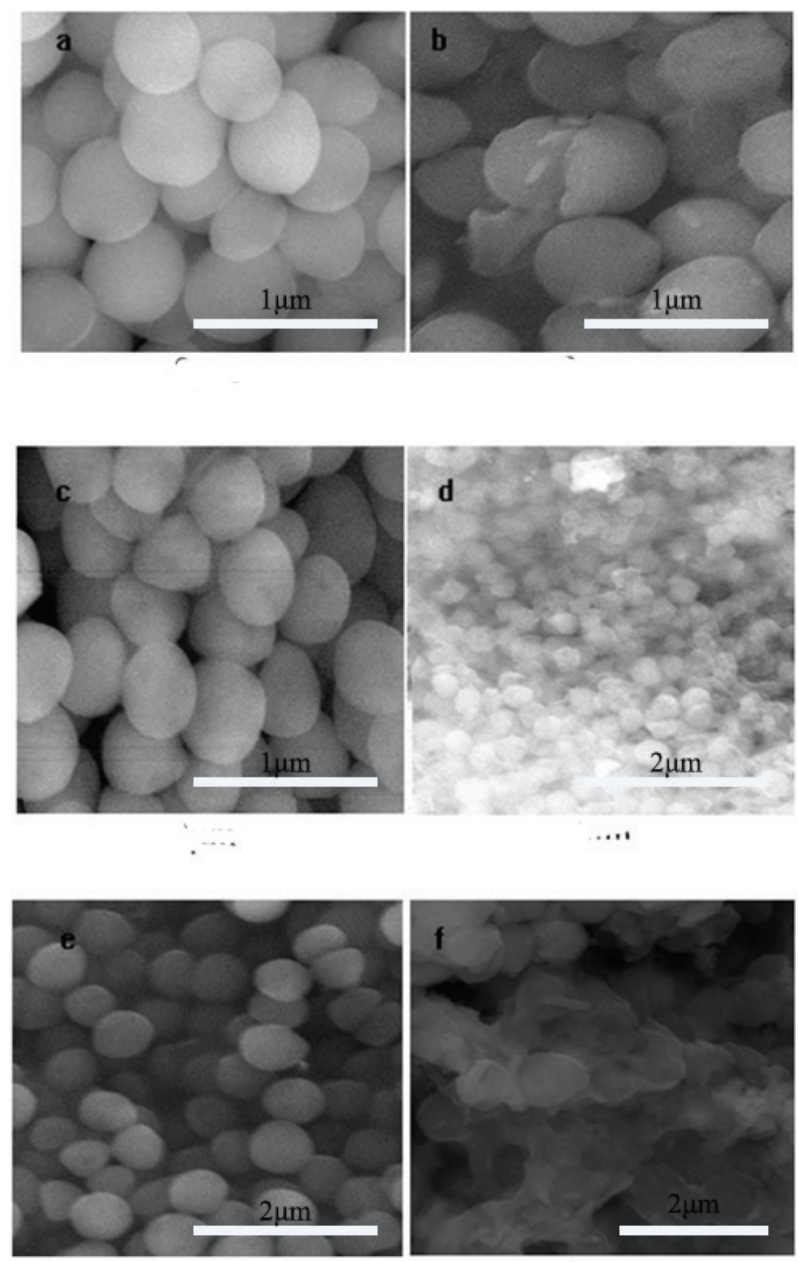

Figure 3: Results of SEM assay. a : SEM of SA; b: SEM of SA treated with corylifolinin at MBC level; $c$ : SEM of MRSA; d:MRSA treated with corylifolinin at MBC level; e : SEM of ESBLs-SA; and d: ESBLsSA treated with corylifolinin at MBC level.

concentration. The higher the concentration, the higher the AKP content was detected. In the Figure 3 (A1, B1 and C1), the AKP leakage level was higher than that of the blank control for 3 hours with the MIC level. The results showed that the cell wall's permeability of three strains could be increased by corylifolinin in a short period of time.

In Figure 3 (A2, B2 and C2), when being treated with corylifolinin at the level of MBC, SA exhibited a higher absorbance as compared with the control group from start to finish. For the other two kinds of Staphylococcus aureus, a higher absorbance was detected before a threehours lapsed.

In general, the results indicated that the cell wall of SA, MRSA and ESBLs-SA could be damaged by corylifolinin at the levels of MIC and MBC.

\subsection{Leakage of extracellular protein caused by corylifolinin}

Protein plays an important role in the life activity of bacterial cells because the accurate expression of bacterial protein is related to the bacterial growth. The increased permeability of the bacterial cell membrane may result in the leakage of intracellular protein into the extracellular protein. The effects of the Diyu tannin extract on the $S$. aureus protein leakage was determined by Liu et al. [22], and the results showed that the leakage of the extracellular soluble protein was positively related to the concentrations of the Diyu tannin extract. By detecting the changes of the extracellular protein leakage, the results indirectly reflected the permeability of the bacterial cell membrane.

In Figure 4 (A1, B1 and $\mathrm{C} 1)$, the treatment with corylifolinin at the MIC level could enhance the leakage of proteins of SA, MRSA and ESBLs-SA. But in time, the amount of the extracellular protein was decreased gradually, which, may be based on the effective decrease in the concentration of corylifolinin and the extracellular protein consumed by the growing bacteria.

The leakage of protein at the level of MBC was shown in Figure 4 (A2, B2 and C2). After three kinds of $S$. aureus were treated at the $\mathrm{MBC}$ level and $2 \times \mathrm{MBC}$ level of corylifolinin, the leakage soluble protein was higher than that of the control group, especially in 3 hours. Then, the soluble protein was slowly reduced. The results suggested that the sterilization effect gradually reduced given a time extension.

As a whole, the leakage of protein indicated that corylifolinin hadcertain effects on the cell membrane of Staphylococcus aureus, methcillin-resistant Staphylococcus aureus and extended spectrum $\beta$-lactamases Staphylococcus aureus. There were positive correlations between the leakage of proteins and the concentration of corylifolinin.

\section{Conclusions}

In general, the antimicrobial activity of corylifolinin against SA, ESBLs-SA at MIC level was stronger than that of MRSA. Results revealed that the MBC of MRSA and ESBLs-SA were equal to their MIC. In addition, the changes of bacterial morphology were observed by SEM, and antibacterial mechanism of corylifolinin were studied by measuring AKP and the extracellular soluble protein content. The mechanism of antibacterial effects mainly included (1) to destroy the cell membrane and bacterial 
A
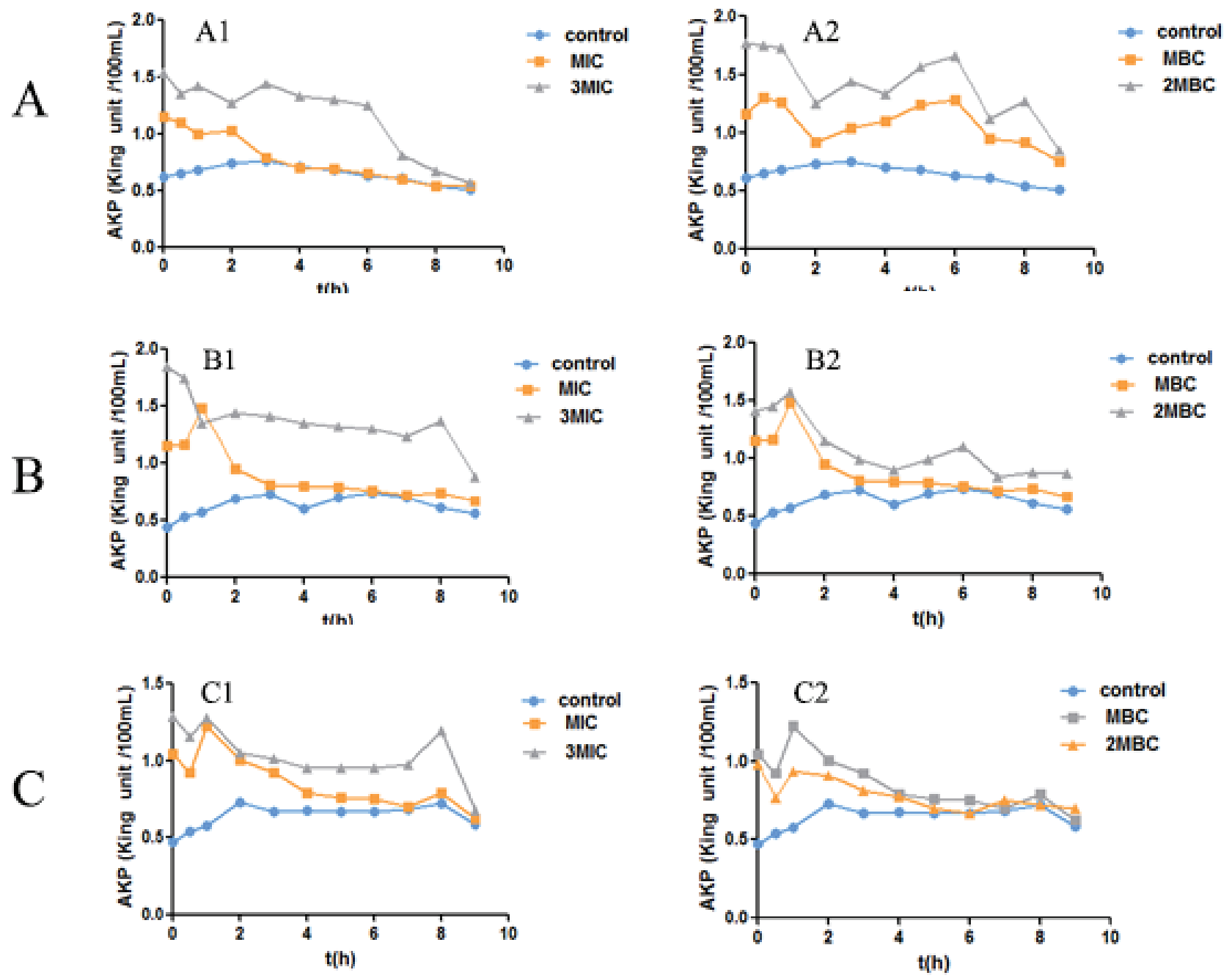

Figure 4: Effects of corylifolinin on leakage of AKP of SA (A), MRSA (B) and ESBLs-SA (C). The activity of AKP extra cellular at the level of MIC (A1, B1, C1); The activity of AKP extcellular at the level of MBC (A2, B2, C2).

cell wall to affect permeability of bacterial membrane;

(2) effect on synthesis of protein and nucleotide; and

(3) inhibition of enzymatic activity of bacteria [23]. We primarily explored the mechanism of corylifolinin on antibacteria by studying the effect of corylifolinin on cell wall and cell membrane. Results showed that there was a positive correlation between the changes in bacterial morphology and the concentration of corylifolinin used to treat bacteria. Striking changes in the content of alkaline phosphatase, extracellular soluble protein took place. All of those results indicated that corylifolinin possessed strong antibacterial effect by bacteriolysis. Further studies on the effect of corylifolinin on DNA, RNA and enzymes of bacteria are needed for further study.
Acknowledgements: This work was supported by Henan Province University Science and Technology Innovation Team (16IRTSTHN019), Kaifeng City Science and Technology Innovation Talent (1509010), National Cooperation Project of Henan Province (2015GH12).

Ethics: We declare that the ethical background to this study was approved by National Ethical Committee.

Conflict of Interest: The authors declared no potential conflicts interest with respect to the research, authorship, and publication of this article. 

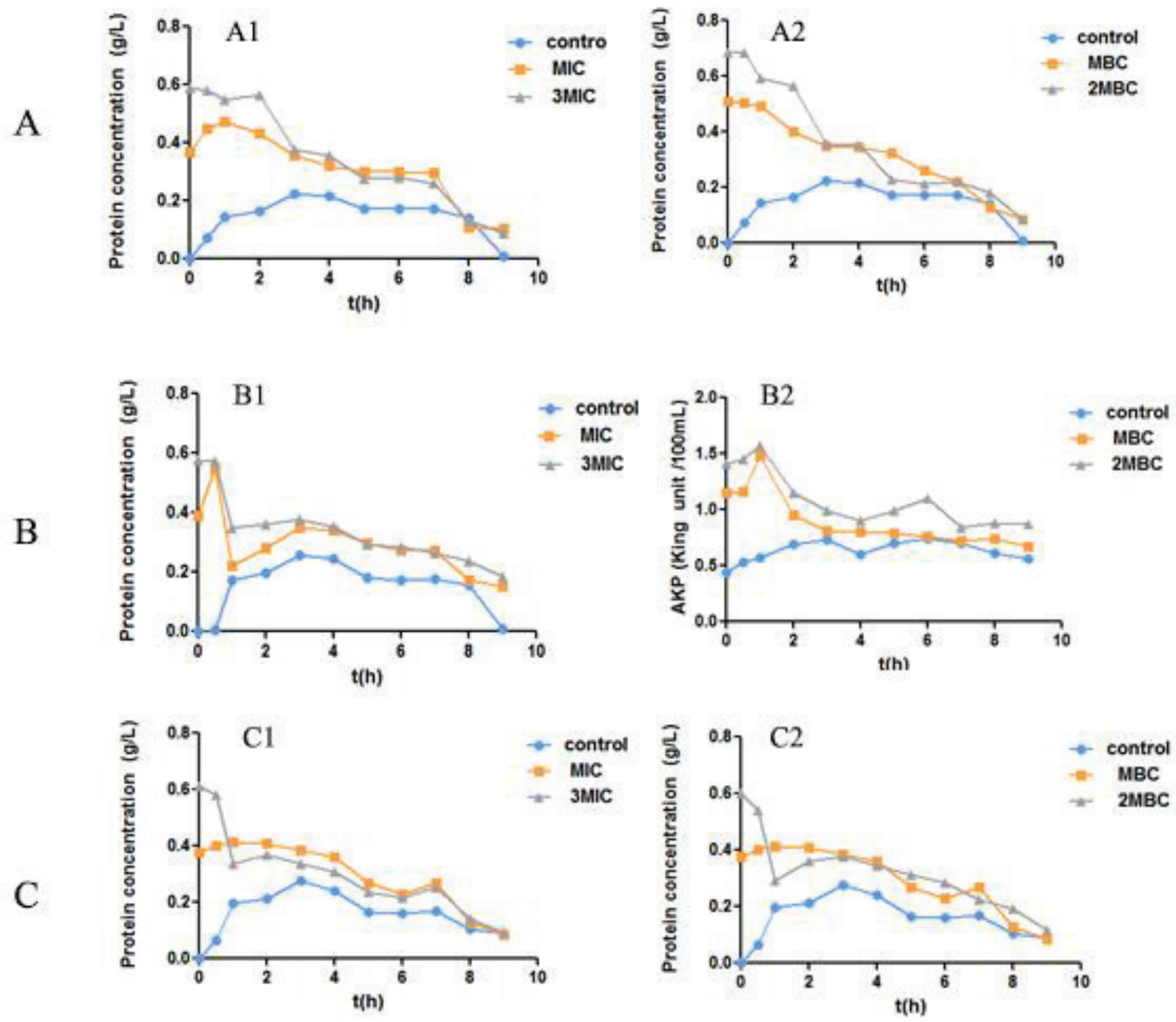

Figure 5: The leakage of extracellular soluble protein from three bacteria which were treated with different concentrations of corylifolinin. A: SA; B: MRSA; C: ESBLs-SA.; ImageA1, B1, C1: The leakage of extracellular soluble protein from three bacteria at MIC. ; ImageA2, B2, C2: The leakage of extracellular soluble protein from three bacteria at MBC.

\section{References}

[1] Luo P., Wang J.J., Li B., Guo Z.J. Liao P.Y., Chen J., Li H.X., Pan W.G., Purification and Identification of Antibacterial Components from Bark of Pterocarya stenoptera C. DC. Nat Prod Res Dev, 2015, 27(2), 246-250.

[2] Gan X.H., Liang Z.Y., Zhou X., Zhao C., Jiang, J. Z., GC-MS Fingerprint and Antimicrobial Activities of Volatile Oils from Pilea aquarum. Chin. J Exp Tradit Med Form, 2015, 17, 63-66

[3] Marina K.Z., Nad D.G., Margarita D., Milenković M., Sisto F., Miani A., Farronato G., Kundaković T., Antibacterial and cytotoxic activities of wild mushroom Fomes fomentarius (L.) Fr., Polyporaceae. Ind Crop Prod, 2016, 79, 110-115. [CrossRef]

[4] Hadjer B., Ihcen K., Amar D., Mellah N., Yousfi M., Antibacterial activity from Rhanterium adpressum flowers extracts depending on seasonal variations. Ind Crop Prod, 2016, 83, 44-47. [CrossRef]

[5] Wang T.X., Yin Z.H., Zhang W., Peng T., Kang W.Y., Chemical constituents from Psoralea corylifolia and their antioxidant $\alpha$-glucosidase inhibitory and antimicrobial activities. China J Chin Mater Med, 2013, 38(14), 2328-2333.

[6] Chinese Pharmacopoeia Committee. The people's Republic of China Pharmacopoeia. Beijing: China Medical Science Press, 2015, 174.

[7] Qiao C.F., Han Q.B., Song J.Z., Mo S,F. Kong L.D., Kung H.F., Xu H.X., Chemical fingerprint and quantitative analysis of Fructus Psoraleae by high-performance liquid chromatography. J Sep Sci, 2007, 30, 813-818. [CrossRef][PubMed]

[8] Kim, K A, Shim, S H, Ahn, H R, Jung, S H.. Protective effects of the compounds isolated from the seed of Psoralea corylifolia on oxidative stress-induced retinal damage. Toxicol Appl Pharm, 2013, 269, 109-120. [CrossRef][PubMed] 
[9] Yu, X, Z.; Zhang, J.; Zhao, M., Zheng G.L., Yu J.P., Total Synthesis of three prenyl flavonoids in fructus psoraleae. Chem. Reagents, 2015, 37(7), 647-650.

[10] Song L.L., Wang W.W., Sun Y., Wei W., Xu H.Z., Sensitive and resistant apoptosis in chronic myelogenous leukemia induced by corylifolinin, J Shanghai Jiaotong Univ Med Sci, 2014, (09), 1309-1314.

[11] Zhang, Y. Peri-implantitic dynamic study on continuous culture of the beneficial bacteria and suspicious pathogens. Master's Thesis, Kunming Medical University, Kunming, China, 2012.

[12] Bouaziz A., Mhalla D., Zouari I., Jlaiel L., Tounsi S., Jarraya R., Trigui. M., Antibacterial and antioxidant activities of Hammada scoparia extracts and its major purified alkaloids. S Afr J Bot, 2016, 105, 89-96. [CrossRef]

[13] Li Z., He M., Dong X., Lin H., Ge H., Shen S., Li J., Ye R.D., Chen D., New erythromycin derivatives enhance $\beta$-lactam antibiotics against methicillin-resistant Staphylococcus aureus. Lett Appl Microbiol, 2015, 60(4), 352-358. [PubMed]

[14] Li H.X., Ren S.S., Li Y., Luo P., Pan G.W., The study of MIC and MBC on Maple naphthoquinone against Common Bacteria. Lishizhen. Med. Mate.r Med. Res. 2012, 23(6), 1422-1424.

[15] Shuai L., Zheng, G, D.; Li D.M., Zhang Q.F., Study on antibacterial effect of extraction from Smilax Clina L. Sci Tech Food Ind, 2015, 36(7), 49-51.

[16] Zhang Y.B., Liu X. Y., Wang Y.F., Jiang P.P., Quek S.Y., Antibacterial activity and mechanism of cinnamon essential oil against Escherichia coli and Staphylococcus aureus. Food Control, 2016, 59, 282-289. [CrossRef][PubMed]
[17] Wan F., Research on antibacterial mechanism of TCMAI to bacteria's wall and cell membrane. Master's thesis. Chengdu University of Traditional Chinese Medicine. Chengdu, China, 2012.

[18] Wang C.J., Chang T., Yang H., Cui M., Antibacterial mechanism of lactic acid on physiological and morphological properties of Salmonella Enteritidis, Escherichia coli and Listeria monocytogenes, Food Control, 2015, 47, 231-236. [CrossRef]

[19] French G.L. Bactericidal agents in the treatment of MRSA infections--the potential role of daptomycin. J Antimicrob Chemother, 2006 , 58(6), 1107-1117. [PubMed]

[20] Zhou B.H., Song C.Q., Jiang S., Wu Y., Antibacterial activity and mechanism of Sanguisorba tannin extracts against Staphylococcus aureus, China. Pharm, 2016, 19(3), 464-468.

[21] Wang, Q.Y., Research progress of alkaline phosphatase and its application. Chinese J Veteri Medic, 2011, 38(1), 157-160.

[22] Liu S.X., Wei H.P., Ceng, J., Yang J.Q., Studies on antibacterial mechanism of the volatile oil from Eupatorium adenophorum antibacterial mechanism of Staphylococcus aureus, Chin J Hosp Pharm, 2012, 32(21), 1742-1745.

[23] Liu Y.N., Li X.F., Ban X.X., Jiang A.W., The review on active antibacterial ingredients of Chinese medicine and the antibacterial mechanism. Global Traditional Chinese Medicine, 2015, 8(08), 1012-1017. [View Article] 